has now been most effectively filled. The sources of information include, notably, the large collection of Siamese birds brought to the British Museum (Natural History) by the late Sir Walter Williamson.

\section{The Worshipful Company of Gardeners' Scholarship}

ApPLICATIONS are invited for a scholarship sponsored by the Worshipful Company of Gardeners, and open to young gardenors who are undergoing or have completed training at the Royal Horticultural Society's Gardens, Wisley, or elsewhere, and who will have had at least four years practical experience in horticulture by October 1. Under present conditions, the scholarship is restricted to male candidates who are unmarried and undortake to remain so during the tenure of the scholarship. The scholarship will be tenable for two years, beginning October 1. The value of the scholarship is $£ 300$ per annum. During the period of the scholarship the holder must be employed, at loast part time, in a horticultural establishment approved by the Gardeners' Company and the Royal Horticultural Society, preferably abroad. Applications should be made to the Secretary, the Royal Horticultural Society, Vincent Square, London, S.W.1, not later than May 31, and should be accompanied by a summary of the applicant's career and qualifications, supporting letters from at least two referees, and a statement showing what post the applicant hopes to obtain and the particular lines of study he would wish to pursue during his tenure of the scholarship.

University News:

Belfast

Dr. J. P. BLAIR has been appointed to a lectureship in mechanical engineering.

Birmingham

THE following appointments have been made: Lecturer, Dr. L. A. Adorjan (mining and minerals engineering); H. S. Bedson (senior lecturer in the Department of Virology and Bacteriology); J. G. Cruickshank (virology and bacteriology); F. J. Fawcett (pathology). Research Fellow, A. Allen (electronic and electrical engineering); D. Beecham (electronic and electrical engineering). Dr. W. I. H. Shedden has been appointed Senior Research Fellow in the Department of Virology and Bacteriology.

East Anglia

THE following appointments to lectureships in the School of Chemical Sciences have been announced: Dr. A. J. Boulton, Dr. M. A. A. Clyne, Dr. R. K. Harris, Dr. K. J. Packer and Dr. F. Wilkinson.

\section{London}

Prof. C. P. Whituingham, professor of botany at Queen Mary College, has been appointed to the chair of plant physiology tenable at the Imperial College of Science and Technology. Dr. S. J. Goldsack, senior lecturer at the Imperial College of Science and Technology, has been appointed to the readership in physics tenable at that College. Dr. Cyril Long, reader in biochemistry at the Institute of Basic Medical Sciences, has been appointed to the Cotton chair of biochemistry tenable at that Institute. The following titles have been conferred: Professor, on Dr. Mary Barber (clinical bac. teriology), in respect of her post at the Postgraduate Medical School of London; on Dr. Victor Gold (chemistry), in respect of his post at King's College; Reader, on Dr. F. W. Chapman (physics), in respect of his post at King's College; on Mr. J. A. Newth (physics), in respect of his post at the Imperial College of Science and Technology.

\section{Valence Defects in Ice}

IN the communication entitled "Valence Defects in Ico", which appeared on p. 490 of the February 1 issue of Nature, Table 1 should read as follows:

\begin{tabular}{lclr}
\multicolumn{2}{c}{ Rotated $D$ defect } & \multicolumn{2}{c}{$X$ defect } \\
$\quad r$ & $1.33 \AA$ & $r$ & $1.5 \AA$ \\
$E_{N}$ & -7 & $E_{N}$ & -7 \\
$E_{L}$ & 3 & $E_{L}$ & 3 \\
$E_{D 1}-E_{N}$ & 5 & $E_{X 1}-2 E_{N}$ & 10 \\
$\Delta E_{D}$ & 4 & $\Delta E_{X}$ & 1 \\
$E_{D L}$ & 19 & $E_{X L}$ & 21
\end{tabular}

Line 16 from bottom of first column should read: "programmed for the Ferranti...". Line 5 from top of second column should read: ". . . the previous values for $E_{L}$ and $E_{N}$ ". The names of the authors are Prof. Norah V. Cohan and Mariana Weissman.

\section{Announcements}

Mr. W. A. DE HAas, president of the Nederlands Atoomforum, has been elected president of Foratom. Foratom was established in Paris in 1960 and incorporates the various national Forums in most of the West European countries, which were set up with the view of promoting the peaceful applications of atomic energy by organizing congresses, symposia, exhibitions, etc.

Dr. Yves O. Fortier, chief of the Economic Geology Division of the Geological Survey of Canada, has been awarded the Royal Canadian Geographical Society's Massey Medal for his contribution to the knowledge of Canadian geography and geology, especially in Arctic regions.

Tre Latin American Representative Office of the Office of Oceanography of Unesco, Paris, is to be contrined within the Facultad de Administración Pública y Comercio, 3er. piso Universidad de Panamá, Panamá, R. de Panamá. All correspondence should be directed to the Liaison Officer for Marine Sciences in Latin America, Apartado Postal 8164, Estafeta Obarrio, Panamá, R. de Panamá.

THE fourteenth annual moeting of the Société de Chimie Physique, entitled "Structure of Polyatomic Radicals", will be held in Bordeaux during May 25-29. Further information can be obtained from Prof. G. Emschwiller, Société de Chimique Physique, 10 rue Vauquelin, Paris 5.

The twelfth Canadian High Polymer Forum, sponsored by the National Research Council of Canada in co-operation with the Chemical Institute of Canada, will be held in Quebec during May 27-29. Further information can be obtained from Dr. H. Daoust, c/o Department of Chemistry, University of Montreal, P.O. Box 6128, Montreal.

A symposIUM on "The Inorganic Constituents of Fuel (Origin, Influence and Control)", organized by the Institute of Fuel (Australian Membership), will be held in the University of Melbourne during May 21-22. Further information can be obtained from Dr. K. S. Basden, c/o Department of Fuel and Combustion Engineering, University of New South Wales, P.O. Box 1, Kensington, New South Wales.

A CONFERENCE on "Thermal Loading and Creep in Structures and Components", arranged by the Council of the Institution of Mechanical Engineers on behalf of the Joint British Committee for Stress Analysis, will be held at the Institution during May 12-14. Topies under discussion will include: philosophy of the design of structures subject to thermal loading; experimental techniques -both theoretical and practical considerations; ineremental collapse and modes of failure arising from combined creep and applied loads; stresses due to transiont effects and to steady thermal states in structures and structural elements. Further information can be obtained from E. J. Millson, Institution of Mechanical Engineors, 1 Birdcage Walk, London, S.W.1. 